\title{
Plasmacytoma Located in the Posterior Mandible: A Case Report
}

\author{
Yavuz Fındık ${ }^{*}$, Timuçin Baykul ${ }^{1}$ and Ummugulsum Alkis ${ }^{2}$ \\ ${ }^{1}$ Department of Oral and Maxillofacial Surgery, Faculty of Dentistry, Süleyman Demirel University, Turkey \\ ${ }^{2}$ Department of Oral Radiology, Faculty of Dentistry, Süleyman Demirel University, Turkey
}

*Corresponding author: Dr. Yavuz Findik, Süleyman Demirel University, Faculty of Dentistry, Department of Oral and Maxillofacial Surgery, Isparta, Turkey, Tel: +902462113251, Fax:+902462370607, E-mail: yavuzfindik32@hotmail.com

\begin{abstract}
Plasma cell neoplasm is characterized by a monoclonal neoplastic proliferation of plasma cells and solitary plasmocytoma of bone (SPB) is a localized form. SPB is most frequently seen in vertebrae and secondarily in long bones. Its presence in jaws is extremely rare. Here we report a unique case of plasmacytoma in the left side of mandible, a chronology for diagnosis of the lesion is also reviewed along with clinical, and radiographic evidence.
\end{abstract}

\section{Keywords}

Plasmocytoma, Mandible, Oral, Bone

\section{Introduction}

Plasmacytoma is a malignant neoplasm caused by the onset and the expansion of a single clone of B lymphoid cells, which are able to evolve up to the stage of plasma cells [1]. Plasmacytoma accounts for $2 \%$ to $3 \%$ of all plasma tumors and very rarely seen in the mandible. The plasma cell neoplasms may present in soft tissue as extramedullary plasmacytoma, in bone as a solitary plasmacytoma of bone, or as part of the multifocal disseminated disease multiple myeloma [2]. Plasma cell neoplasm of the bones of the jaw is rare. Plasma cells produce osteoclast-activating factors, which stimulate the growth of osteoclasts and therefore bone resorption occur [3]. Plasmacytomas usually appear on radiographic images as radiolucent areas. We here report a patient who had solitary plasmacytoma of the left mandible with its clinical, and radiographical findings.

\section{Case Report}

A 58-year-old female was referred to the Oral and Maxillofacial Surgery Department of the Suleyman Demirel University, Isparta, Turkey, complaining of light pain and hypoesthesia in the left mandible. No deformity was seen extraorally. Clinical examination revealed a tender swelling at the left mandibular molar region. Tongue, lips, buccal and alveolar mucosa were normal in appearance and there was no sign inflammation or pathological view in intraoral examination. Head and neck lymph nodes were normal. An orthopantogram revealed and a typical radiolucency was seen (Figure 1). The lesion extended from the left edentulous mandibular premolar area to the molar area and measured approximately $5 \times$ $3 \mathrm{~cm}$. From her medical history, patient was undergoing treatment for goiter, because of the swelling in her neck region for a year at another

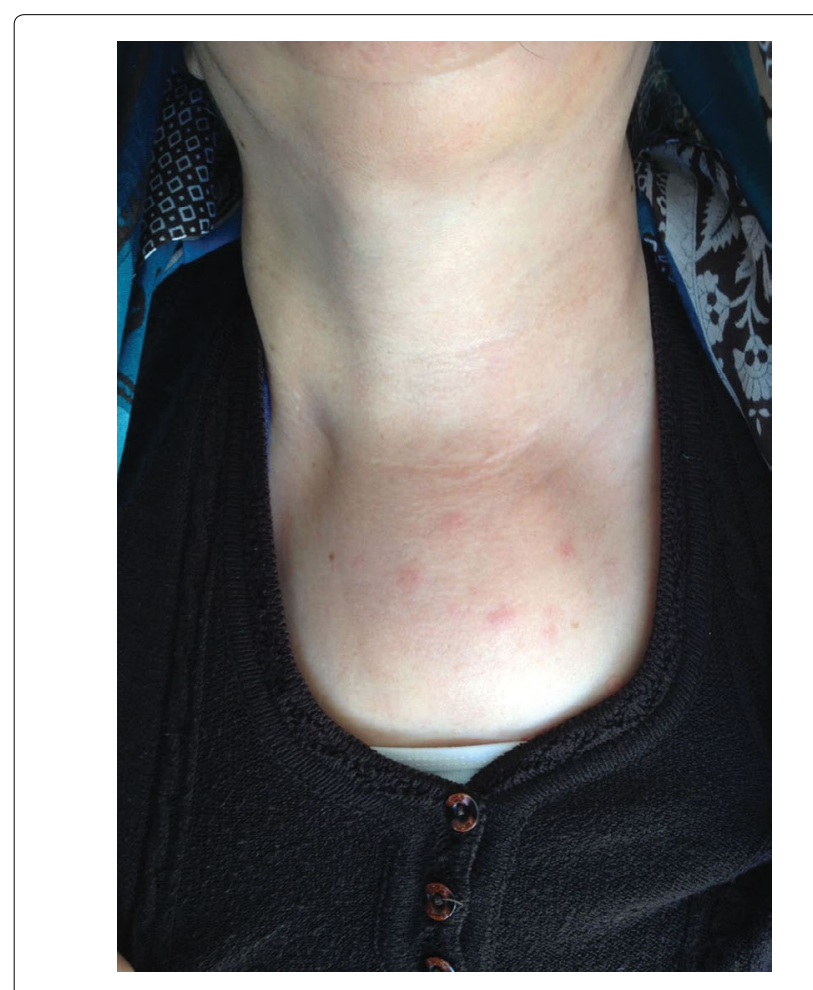

Figure 1: Subcutaneous soft tissue swelling on the surface of sternum.

center but no additional treatment or diagnosis was investigated why this swelling was occurred. The patient had a subcutaneous soft tissue swelling on the surface of sternum for a year which was the specific view of the plasmacytoma (Figure 2). An incisional biopsy was taken from the mandible under local anesthesia. The histological features were sheets of atypical plasma cells. Histopathological examination was reported as solitary plasmocytoma. After the diagnosis of plasmocytoma, no surgical treatment were done, and patient was referred to the oncology service for treatment. The patient was treated with multiagent chemotherapy and prescribed thalidomide, and dexamethasone at another center. A panoramic radiograph taken 12 months later demonstrated a prominent bone formation and cortical outlines of the affected mandible and the inferior alveolar canal (Figure 3). The patient had tolerated the chemotherapy well until

\section{Clinmed International Library}

Citation: Fındık Y, Baykul T, Alkis U (2015) Plasmacytoma Located in the Posterior Mandible: A Case Report. Int J Oral Dent Health 1:011

Received: June 25, 2015: Accepted: August 01, 2015: Published: August 03, 2015

Copyright: ( 2015 Fındık Y. This is an open-access article distributed under the terms of the Creative Commons Attribution License, which permits unrestricted use, distribution, and reproduction in any medium, provided the original author and source are credited. 


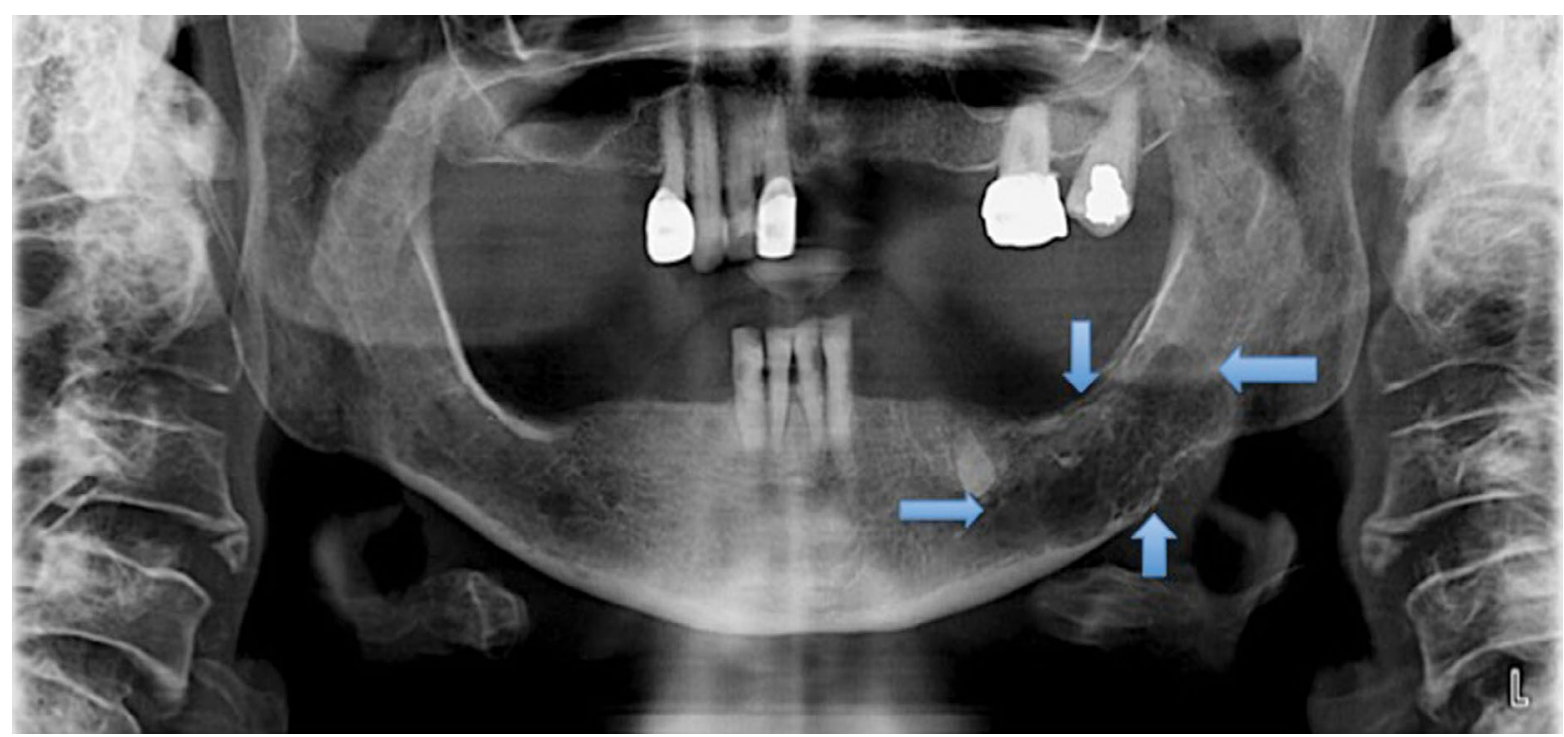

Figure 2: A typical radiolucency was seen on the orthopantogram.

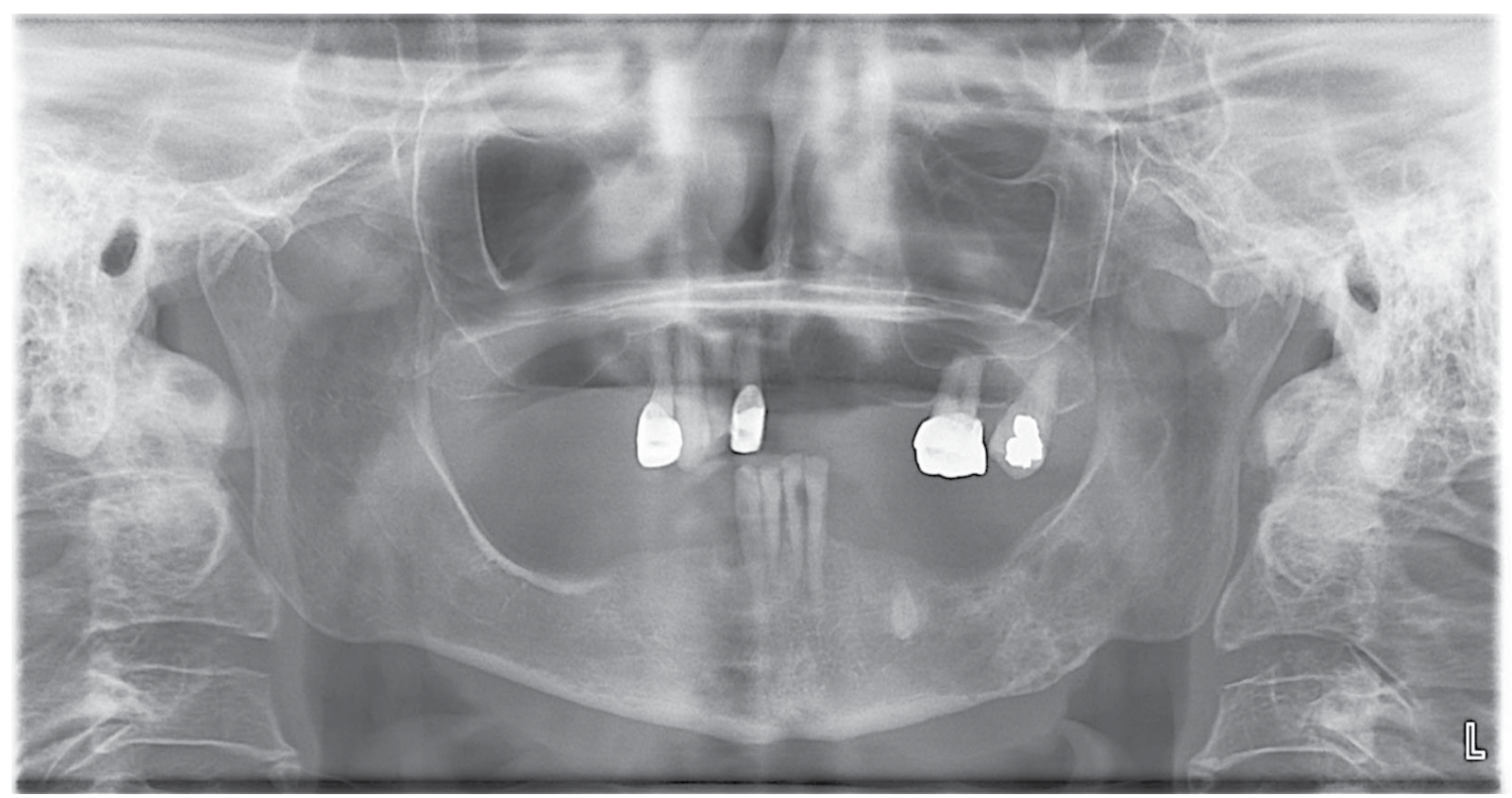

Figure 3: 12 months later demonstrated a prominent bone formation and cortical outlines of the affected mandible and the inferior alveolar canal

now. No additional foci of disease or evidence of recurrence were noted during a 15-month follow-up period. Early diagnosis of this kind of lesion is very important for treating the disease without any surgical management.

\section{Discussion}

Solitary plasmacytoma is characterized by the collection of monoclonal plasma cells in the bones. It is seen generally in long bones but rarely occurred in the jaws and only $4.4 \%$ of SPB seen in the mandible. Most common clinical symptoms of SPB are pain in the jaws and teeth with paraesthesia/anesthesia, mobility and migration of the teeth, hemorrhage, swelling in hard and soft tissues and pathological fractures [4]. But plasmacytoma do not show any characteristic sign related to the tumor. In our presented case, sensivity at the left mandibular molar area, was the major symptom and pain, hypoesthesia was present but paraesthesia was not reported. No pathological fracture was seen. Clinically plasma can be present with bone pain, localized swelling of the area involved or with pressure symptoms on the surrounding structures. Solitary bone plasmacytomas usually appear in the bones of vertebrae, ribs, pelvis and pectoral girdle while extramedullary plasmacytomas usually appear on the mucosal surfaces e.g. nasal sinuses, oropharynx, larynx etc [5]. In our case, soft tissue swelling was seen between the lower neck to upper sternum area [6]. Based on the multilocular radiolucent lesion of the mandible on orthopantomograph, the differential diagnosis for this lesion included ameloblastoma, odontogenic myxoma, keratocystic odontogenic tumor; central giant cell granuloma; aneurysmal bone cyst; and metastatic carcinoma. Biopsy and other clinical findings may be evaluated together for proper diagnosing the lesion. Misdiagnosis of the lesion, such our lesion, may process the diseases so early diagnosis is essential to overall patient survival. And regular clinical follow up with monitoring of immunoglobulins and monoclonal proteins in serum and BenceJones proteins in urine is advised.

\section{References}

1. Souza LN, Farias LC, Santos LA, Mesquita RA, Martelli H Jr, et al. (2007) Asymptomatic expansile lesion of the posterior mandible. Oral Surg Oral Med Oral Pathol Oral Radiol Endod 103: 4-7.

2. Burns JA, lezzoni JC, Reibel JF, Park SS (1999) Extensive extramedullary amyloid-rich plasmacytoma of the mandible. Otolaryngol Head Neck Surg 120: 937-939.

3. Millesi W, Enislidis G, Lindner A, Schobel G, Ewers R, et al. (1997) Solitary 
plasmocytoma of the mandible-a combined approach for treatment and reconstruction. Int J Oral Maxillofac Surg 26: 295-298.

4. Baad R, Kapse SC, Rathod N, Sonawane K, Thete SG, et al. (2013) Solitary plasmacytoma of the mandible - a rare entity. J Int Oral Health 5: 97-101.
5. Owotade F, Ugboko V, Ajike S, Salawu L, Amusa Y, et al. (2005) Head and neck manifestations of myeloma in Nigerians. Int J Oral Maxillofac Surg 34 761-765.

6. Nofsinger YC, Mirza N, Rowan PT, Lanza D, Weinstein G (1997) Head and neck manifestations of plasma cell neoplasms. Laryngoscope 107: 741-746. 